\title{
EVALUATION OF THE REVERBERATION TIME IMPROVEMENT IN A SPEAKING HALL
}

\author{
FLORIN MARIAN NEDEFF ${ }^{* 1}$, MARCEL AGOP ${ }^{2,3}$, EMILIAN FLORIN \\ MOȘNEGUȚU ${ }^{1}$, NARCIS BARSAN ${ }^{1}$ \\ ${ }^{1}$, Vasile Alecsandri” University of Bacau, Romania \\ ${ }^{2}$, Gheorghe Asachi” Technical University of Iași, Romania \\ ${ }^{3}$,Alexandru Ioan Cuza” University of Iasi, Romania
}

\begin{abstract}
To improve a room's acoustic parameters there have been studied several variants of acoustic materials and devices that can be placed on the ceiling of the hall. The main objective of the study was the reverberation time measurement and calculation. By using the acoustic panel made from polystyrene, covered with jute on the both sides, has ensured the largest reverberation time decrease. Thus, we can say that the analyzed room can be used for speech activity (courses, conferences etc.)
\end{abstract}

Keywords: reverberation time, acoustic materials, acoustic parameters, panels

\section{INTRODUCTION}

The speaking halls used in special for oral communication (seminars, courses, conferences, etc.), must ensure the best possible conditions so that the words emitted by the source (speaker) are collected by the receiver (listener) in an more understandable way [1-3].

Reverberation time is the main parameter that can express the acoustic quality of a room (it is an objective parameter) [4]. Express "vivacity" of a room is linked to the geometric characteristics of the room (volume, area), but also depending on the properties of the materials used in the construction and arrangement of the room $[5,6]$. To determine the calculated reverberation time in a room the most frequently used formula is the W.C. Sabine empirical formula:

$$
T 60=\frac{0.16 \cdot V}{4 m \cdot V+A b_{t o t}}(\mathrm{~s})
$$

where: $V$ represents the room volume; $4 m \cdot V$ - air absorption ( $\mathrm{m}$ is the air absorption coefficient); $A b_{\text {tot }}$ overall sound absorption of the room.

The $4 m \cdot V$ factors are related to the air absorption from the room and can be ignored for small rooms. In these cases, the reverberation time can be determined by the equation $[7,8]$ :

$$
T 60=\frac{0.16 \cdot V}{A b_{\text {tot }}}=\frac{0.16 \cdot V}{\alpha_{m e d} \cdot S_{\text {tot }}}
$$

where: $\alpha_{\text {med }}$ represents the average absorption coefficient of materials, objects and the people from the room; $S_{\text {tot }}$ $i$ area of the walls, ceiling, floor, furniture objects and people from the room.

${ }^{*}$ Corresponding author, email: florin nedeff@yahoo.com

(C) 2016 Alma Mater Publishing House 
Reverberation time differs for the same room in the unpopulated (T60n) or populated (T60p) situation with a difference of time (DT), which differs depending on the frequency $[9,10]$, respectively:

$$
T 60 p=T 60 n-D T
$$

Reverberation time can affect the intelligibility during conversations and sound attenuation to twice of the distance. In the case of a shorter reverberation time, the intelligibility of conversation is improved and sound attenuation increased. Also, the reverberation time decreases with frequency increasing [8, 10-13].

\section{EXPERIMENTAL SETUP}

For this study were used the following equipment, materials and standards: Equipment (2270 portable analyzer; Omni Power Type 4292-L Sound Source); Tested Materials (OSB panels $6 \mathrm{~mm}$ thick; Polystyrene panels with 38 mm thickness; plasterboard panels with $12.4 \mathrm{~mm}$ thickness); Standards [14, 15]: ISO 3382-3:2112 Open offices acoustic and ISO 3382-2:2009 - Measurement of acoustic parameters for rooms.

In Figure 1 is presented the analyzed room and Figure 2 shows the outline of the acoustic device (panel). The panels were mounted by using metallic frames. The 21 acoustic devices were positioned in two rows on the ceiling of the room (Figure 3 and 4).

The acoustic devices (panels) can be rotated in two planes of the room, longitudinal and horizontal. The total area of the panels on one side was $36,225 \mathrm{~m}^{2}$. The room dimensions was: length, width, height, $\left(\mathrm{Lxlxh}=19,55 \times 4,65 \times 2,72=247,27 \mathrm{~m}^{3}\right)$.

Measurements were performed without population in room. It has taken in to account all the objects in the room (8 tables, 64 chairs, window curtain, radiators etc.) (Figure 4).

Experimental technique (the working mode) is presented in Table 1. The reverberation times T20 and T30 were measured and was calculated the average (T60) for each of the six frequencies.

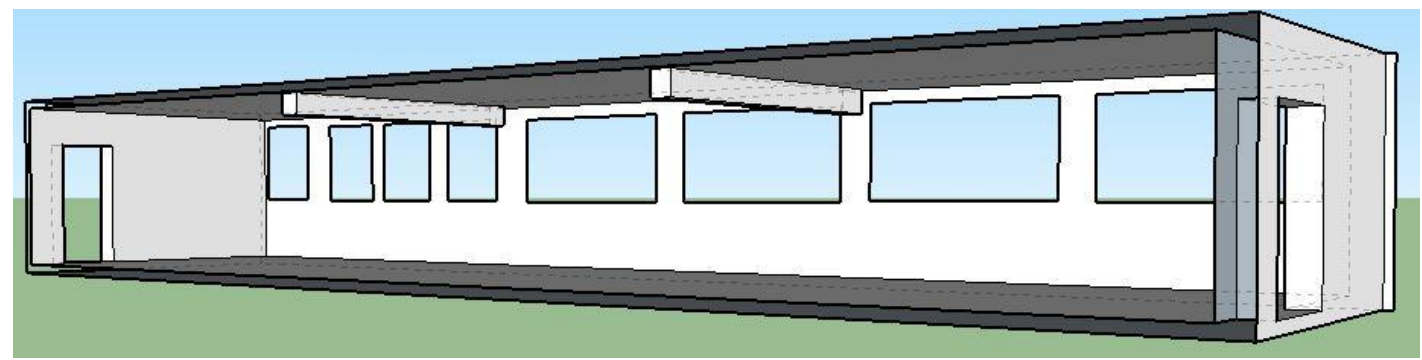

Fig. 1. Scheme of the analyzed hall.

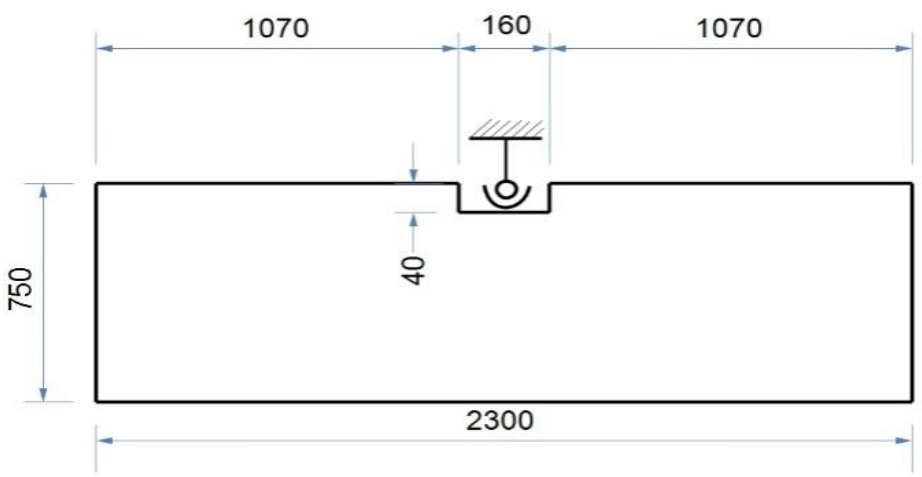

Fig. 2. The dimension of metallic frame used for acoustic panels (in $\mathrm{mm}$ ). 


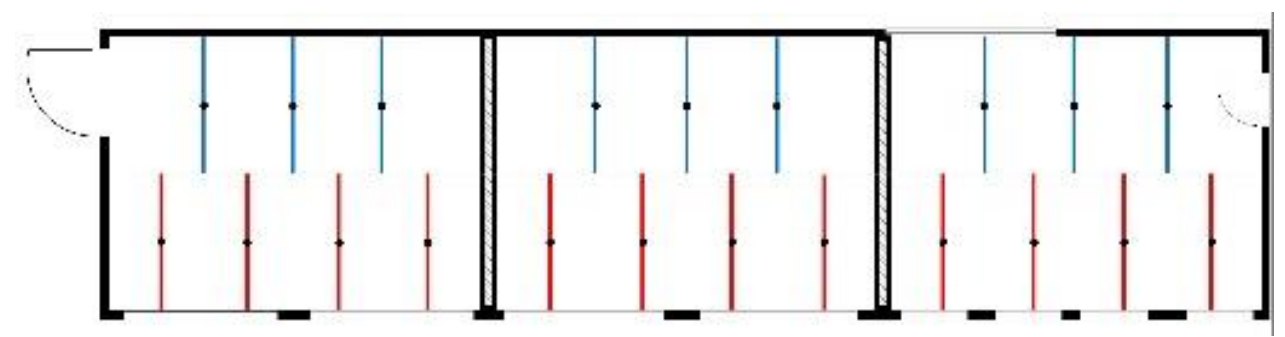

Fig. 3. Panels positioning on the room ceiling.

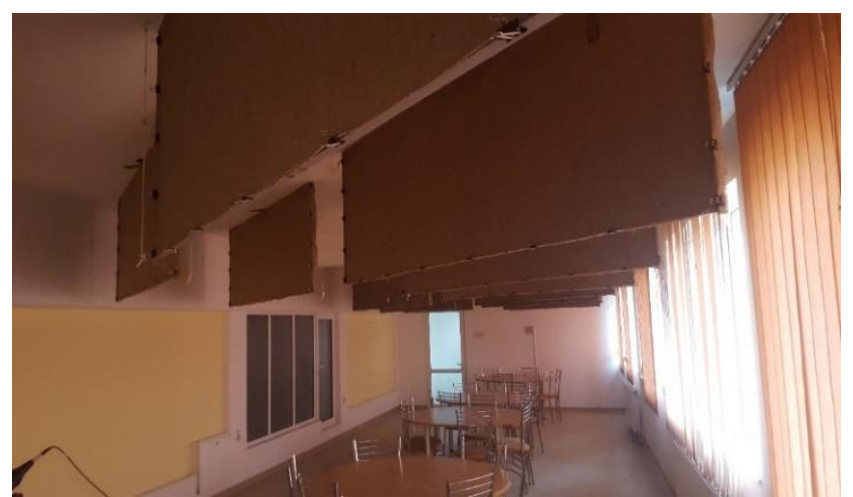

Fig. 4. Image with acoustic OSB panels, covered with jute, placed "V2" position.

Table1. Working methods for measurements.

\begin{tabular}{|c|c|}
\hline Method code & Explanations \\
\hline V1 & Room ceiling without acoustic panels \\
\hline O & Room ceiling with 21 OSB acoustic panels \\
\hline O+I & Room ceiling with 21 OSB acoustic panels covered with jute on a side \\
\hline O+2I & Room ceiling with 21 OSB acoustic panels covered with jute on two side \\
\hline $\mathbf{P}$ & Room ceiling with 21 polystyrene acoustic panels \\
\hline $\mathbf{P + I}$ & Room ceiling with 21 polystyrene acoustic panels covered with jute on a side \\
\hline $\mathbf{P + 2 I}$ & Room ceiling with 21 plasterboard acoustic panels \\
\hline $\mathbf{R}$ & Room ceiling with 21 plasterboard acoustic panels covered with jute on a side \\
\hline $\mathbf{R + I}$ & Room ceiling with 21 plasterboard acoustic panels covered with jute on two side \\
\hline $\mathbf{R + 2 I}$ &
\end{tabular}

\section{RESULTS AND DISCUSSION}

The reverberation time measured was in a narrow range of values, $(0.77 \div 1.96)$ seconds, based on the six analyzed frequencies. The lower time value measured was obtained at a frequency of $4000 \mathrm{~Hz}$ and the higher at the $500 \mathrm{~Hz}$ frequency, for all analyzed materials, in the case of unpopulated room.

The reverberation time was analyzed for different materials (Table 1) assembled in panels form (Figure 4).

Figure 5 presents comparative variation of reverberation time in the case of OSB, polystyrene and plasterboard acoustic panels used.

To identify the influence of some grouped materials, there were analyzed both simple panels and covered panels (jute on one side of the panel) or (jute on both sides of the panel). For simple OSB panels, OSB with jute on one side of the panel and jute on both sides of the panel the variation of reverberation time is presented in Figure 6.

For the same groupings of experimentation but using polystyrene, the T60 curves are presented in Figure 7. Also in the case of plasterboard acoustic panels used, the Figure 8 reveals the variation of reverberation time. 


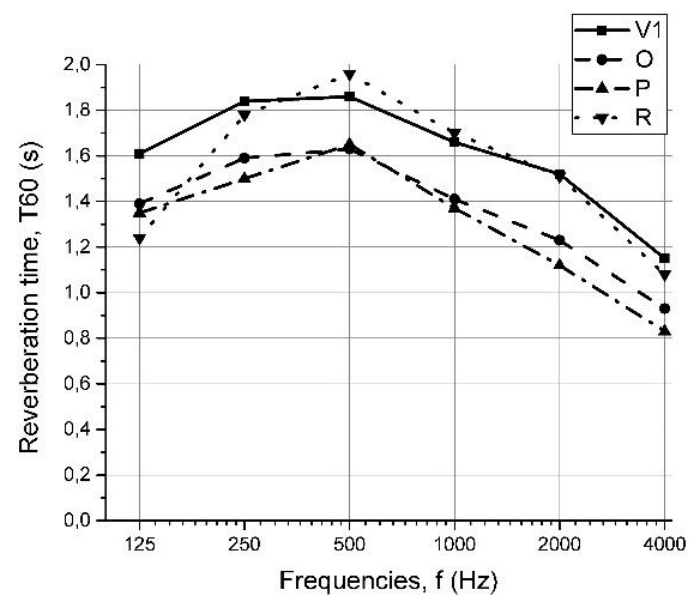

Fig. 5. Reverberation time variation, on the six frequencies, for OSB $(\mathrm{O})$, polystyrene $(\mathrm{P})$ and plasterboard $(\mathrm{R})$ panels in comparison with cleared ceiling (V1).

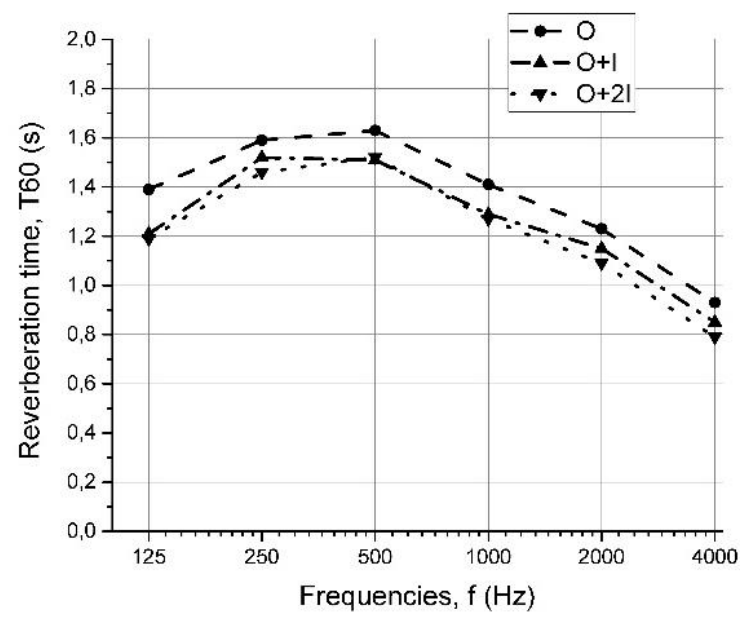

Fig. 6. Reverberation time variation, on the six frequencies, for simple OSB panels $(\mathrm{O})$, with jute on one side $(\mathrm{O}+\mathrm{I})$, with jute on two sides $(\mathrm{O}+2 \mathrm{I})$.

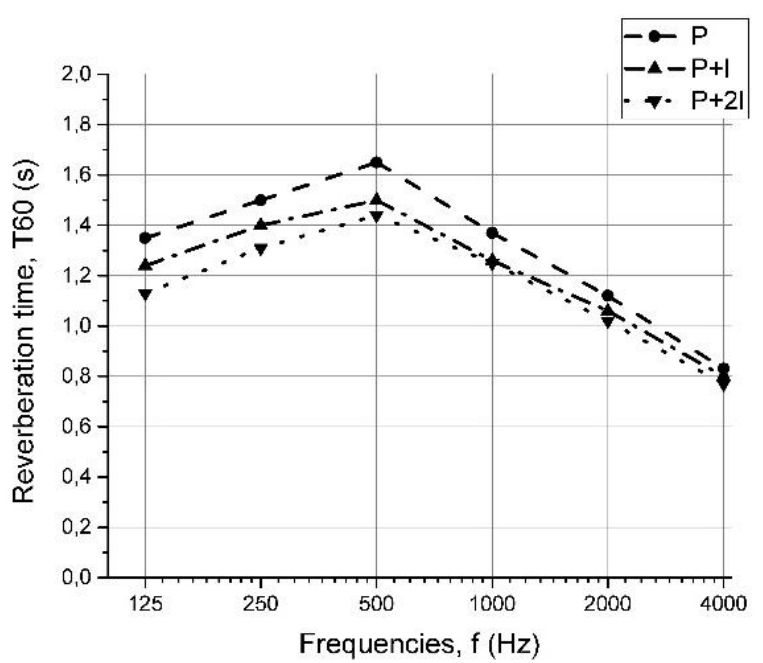

Fig. 7. Reverberation time variation, on the six frequencies, for simple polystyrene $(\mathrm{P})$, with jute on one side $(\mathrm{P}+$ I) and with two sided Jute $(\mathrm{P}+2 \mathrm{I})$ panels. 


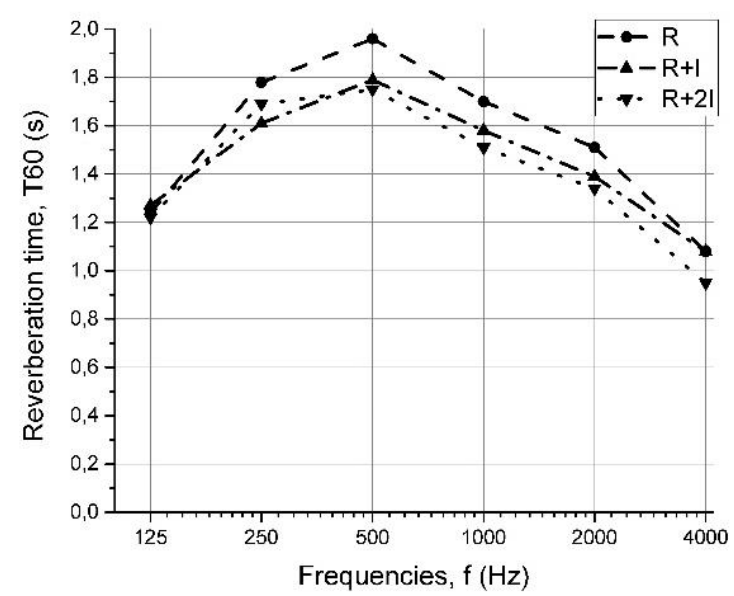

Fig. 8. Reverberation time variation, on the six frequencies, for simple plasterboard (R), with jute on one side $(\mathrm{R}+\mathrm{I})$ and with two sided Jute $(\mathrm{R}+2 \mathrm{I})$ panels.

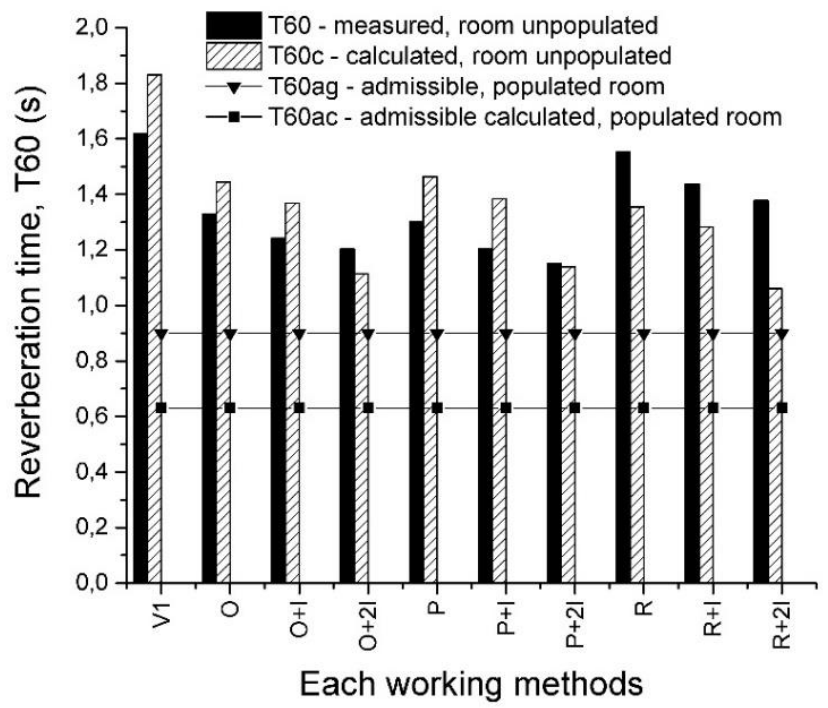

Fig. 9. Variation of reverberation time measured, calculated and admissible values.

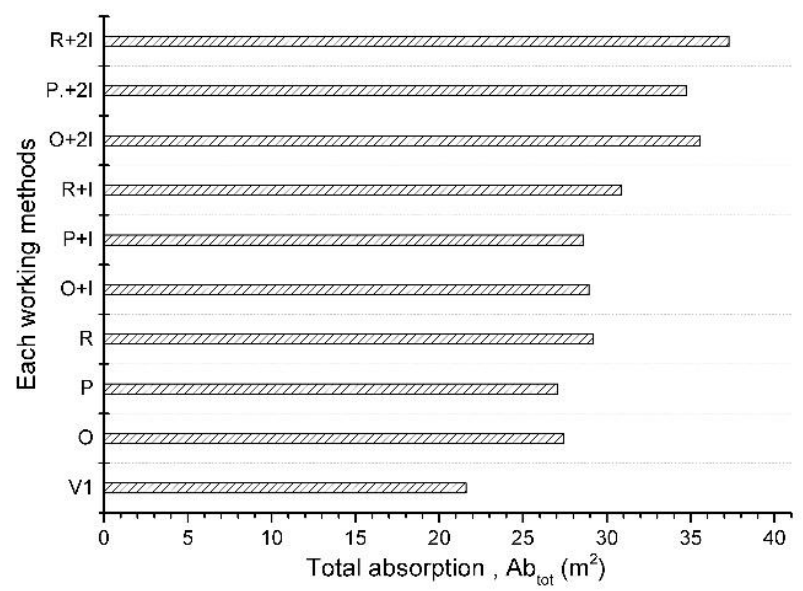

Fig. 10. Variation of total absorption for each working methods. 
The arrangement of room's ceiling (as was present in the Table 1) has ensured some absorbing surfaces between $21.6 \mathrm{~m}^{2}$, in the case of room's ceiling without acoustic panels and up to a maximum of $37.3 \mathrm{~m}^{2}$ for using plasterboard acoustic panels covered on the both sides with jute (Figure 10).

The differences between calculated reverberation time with Sabine's equation and measured reverberation time related to the allowable values of reverberation time for a speaking hall are presented in Figure 9.

\section{CONCLUSIONS}

Reverberation time varies with the frequency indifferently of all situations used to arrange the room's ceiling. The measurements were performed on third octave frequency, according to the reverberation time measuring standard, to cover all the situations that may occur in a speaking hall.

The differences between the measured and calculated values with Sabine equation are small and are according to ISO 3382-2: 2009 standard. In addition, the small differences in the values reveals the correct calculation methods, used for surface absorption and absorption coefficients of materials from the studied hall.

Compared to 1.62 seconds reverberation time measured in the unarranged room, all the material used to arrange the room's ceiling did a significant reduction of the reverberation time values.

The best materials, which significantly reduced the $\mathrm{T}_{60}$ value, were polystyrene panels with jute on both sides $(1.15$ s) and OSB with jute on both sides $(1.20 \mathrm{~s})$. For these two variants, total absorption surface was $34.8 \mathrm{~m}^{2}$ and respectively $35.5 \mathrm{~m}^{2}$.

\section{REFERENCES}

[1] Fahy, F., Foundations of engineering acoustics, Academic Press, London, 2005.

[2] Stremțan, F.A., Cercetări privind modelarea, simularea şi dezvoltarea structurilor acustice, Teză de doctorat, Universitatea Tehnică din Cluj-Napoca, 2013.

[3] Sundberg, J., The acoutics of the singing voice, Scientific American, 1977, vol. 236, no. 3.

[4] Gaubitch, N.D., Lollmann, H.W., Jeub, M., Falk, T. H., Naylor, P.A., Vary, P., Brookes, M., Performance comparison of algorithms for blind reverberation time estimation from speech, International Workshop on Acoustic Signal Enhancement 2012, 4-6 September 2012, Aachen, Germany.

[5] http://oa.upm.es/33037/1/TFG_adrian_sanchez_jimenez.pdf (26.10.2016).

[6]http://www.tnw.tudelft.nl/fileadmin/Faculteit/TNW/Over_de faculteit/Afdelingen/Imaging_Science_and_Tec hnology/Research/Research_Groups/Acoustical_Imaging_and_Sound_Control/Publications/M.Sc._thesis/doc/G erben_Zeilstra_20090827.pdf (12.11.2016).

[7] Kuttruff, H., Room acoustics, Spon Press, London, UK, 2009.

[8] http://www.isover.ro/confort-acustic/acustica-ncaperilor-216.html (20.11.2016).

[9] Bradley, J.S., A comparison of three classical concert halls, The journal of the acoustical Society of America, vol. 89, no. 3, 1991, p.1176-1192.

[10] Norbert, Ș.T., Contribuții la evaluarea și modelarea acusticii încăperilor, Teză de doctorat, Universitatea Tehnică din Cluj Napoca, 2011.

[11] Lăzărescu Tomozei, C.M., Studii și cercetări privind posibilităţile de reducere a poluării fonice din instalațiile industriale, Teză de doctorat, Universitatea „Vasile Alecsandri” din Bacău, 2011.

[12] http://www.instal.utcb.ro/conferinta_2010 (10.12.2016).

[13] https://architettura.unige.it/did/12/architettura/terzo0809/fisicatecnica/capitoli/app2_II.pdf (15.12.2016).

[14] ISO 3382-2:2009, Measurement of room acoustic parameters -- Part 2: Reverberation time in ordinary rooms.

[15] C125: 2013, Normativ privind acustica în construcții și zone urbane. 